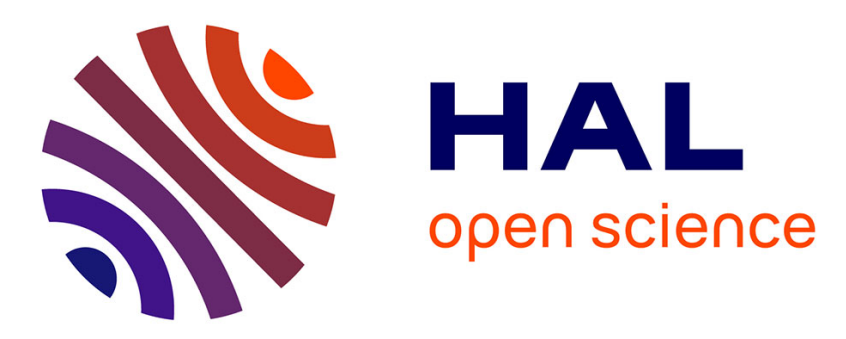

\title{
Association of sickle avascular necrosis with bone morphogenic protein 6
}

Pinar Ulug, Nisha Vasavda, Moji Awogbade, Juliette Cunningham, Stephan Menzel, Swee Lay Thein

\section{- To cite this version:}

Pinar Ulug, Nisha Vasavda, Moji Awogbade, Juliette Cunningham, Stephan Menzel, et al.. Association of sickle avascular necrosis with bone morphogenic protein 6. Annals of Hematology, 2008, 88 (8), pp.803-805. 10.1007/s00277-008-0659-5 . hal-00535012

\section{HAL Id: hal-00535012 https://hal.science/hal-00535012}

Submitted on 11 Nov 2010

HAL is a multi-disciplinary open access archive for the deposit and dissemination of scientific research documents, whether they are published or not. The documents may come from teaching and research institutions in France or abroad, or from public or private research centers.
L'archive ouverte pluridisciplinaire HAL, est destinée au dépôt et à la diffusion de documents scientifiques de niveau recherche, publiés ou non, émanant des établissements d'enseignement et de recherche français ou étrangers, des laboratoires publics ou privés. 


\title{
Association of sickle avascular necrosis with bone morphogenic protein 6
}

\author{
Pinar Ulug • Nisha Vasavda • Moji Awogbade • \\ Juliette Cunningham • Stephan Menzel • \\ Swee Lay Thein
}

Received: 12 August 2008 / Accepted: 1 December 2008 /Published online: 18 December 2008

(C) Springer-Verlag 2008

\begin{abstract}
Dear Editor,
Avascular necrosis (AVN) of femoral and humeral heads is a frequent and debilitating complication in patients with sickle cell disease (SCD), its prevalence being highest in individuals with SCD-Hb SS and coincidental $\alpha$-thalassemia. Family and sibling studies suggest a genetic predisposition, and recently, variation in genes involved in bone modeling or the vasculature have been proposed as significant factors in the development of AVN [1]. Baldwin et al. [1] investigated single nucleotide polymorphisms (SNPs) in candidate genes involved in vascular function, inflammation, oxidant stress, and endothelial cell biology for association with AVN. SNPs in bone morphogenic protein 6 (BMP6), annexin A2 (ANXA2), and klotho $(K L)$ genes were suggested to be associated with sickle cell AVN. We attempted to replicate this association in 244 adult patients with SCD, 39 of whom had joint symptoms with radiological and/or magnetic resonance imaging
\end{abstract}

P. Ulug $\cdot$ N. Vasavda $\cdot$ J. Cunningham $\cdot$ S. Menzel $\cdot$ S. L. Thein King's College London School of Medicine,

Division of Gene and Cell Based Therapy,

Denmark Hill Campus,

London SE5 9NU, UK

M. Awogbade $\cdot$ S. L. Thein

King's College Hospital,

Department of Haematological Medicine,

Denmark Hill,

London SE5 9RS, UK

S. L. Thein $(\bowtie)$

King's College London School of Medicine,

King's Denmark Hill Campus, James Black Centre,

125 Coldharbour Lane,

London SE5 9NU, UK

e-mail: sl.thein@kcl.ac.uk
(MRI) evidence of AVN (AVN group; cases), whereas the remaining 205 had no clinical symptoms of AVN (nonAVN group; controls). Those with AVN, on average, were 3 years older than the controls (Table 1). In addition, individuals with AVN had a higher prevalence of coincidental $\alpha$-thalassemia, higher hematocrit levels, and lower fetal hemoglobin ( $\mathrm{Hb} \mathrm{F}$ ) levels when compared to the nonAVN group, though these observations were not statistically significant (Table 1). All patients were of West African or African Caribbean descent. The study was approved by the King's College Hospital Research Ethics Committee (LREC 01-083).

Based on the visual inspection of phased haplotypes in the Yoruba population from Ibadan, Nigeria (YRI), two haplotype blocks were defined in $K L$, one block in $A N X A 2$, and three blocks in BMP6. Tag SNPs with population frequency information were then selected using the HapMap Project data provided for the Yoruba community, as this ethnic group relates most closely to our sample population. Of the selected tag SNPs, one per gene was identical to that used by Baldwin et al. (Table 2).

The selected tag SNPs were genotyped using the TaqMan ${ }^{\circledR}$ allelic discrimination assay. Most assays performed well, but ANXA2-2 failed repeatedly. Genotype data generated from the SNP assays for the remaining six markers ranged from $95.2 \%$ to $100 \%$ complete, and markers displayed no deviation from the Hardy-Weinberg equilibrium.

To test for trait association with the candidate SNPs, allele frequencies between cases (AVN group) and controls (non-AVN group) were compared using Pearson's chisquare statistic with a significance threshold of $p \leq 0.05$ (Table 2). Characterization of the six SNP markers revealed that only one (BMP6-3 or rs3812163) showed significant evidence of association $(p=0.021)$ with AVN. 
Table 1 Comparison of AVN and non-AVN patients



'Unknown' indicates missing data "\%" denotes percentage of patients

$\mathrm{Hb}$ hemoglobin, $\mathrm{HCT}$ hematocrit, $\mathrm{Hb} F \%$ percentage fetal hemoglobin

This case-control study on the association between the occurrence of sickle AVN and a small set of genetic polymorphisms was designed to replicate recent findings implicating the involvement of $K L, B M P 6$, and $A N X A 2$ in the occurrence of AVN in patients with SCD. Six tag SNPs covering the major haplotypes representing the three genes were selected. Our study confirmed association of a single SNP, BMP6-3 (rs3812163), suggesting a potential role for BMP6 in the development of AVN in SCD patients.
Members of the BMP family are unique in their ability to induce endochronal bone formation when implanted at ectopic sites [2]. In the past, BMP6 mRNA has been localized in hypertrophic cartilage [3]. More recently, when Bobacz et al. [4] investigated the role of BMP6 in cartilage homeostasis, they discovered a crucial involvement of this gene in the maintenance/repair of human articular cartilage. In AVN, the progressive degeneration of bone eventually leads to its collapse and destruction of the articular

Table 2 Selected tag SNPs for typing in bone morphogenic protein 6 (BMPO), annexin A2 (ANXA2), and klotho (KL)

\begin{tabular}{|c|c|c|c|c|c|c|c|}
\hline \multirow[t]{2}{*}{ SNP ID } & \multirow[t]{2}{*}{$\begin{array}{l}\text { Given } \\
\text { name }\end{array}$} & \multirow[t]{2}{*}{$\begin{array}{l}\text { Chromosomal } \\
\text { position }\end{array}$} & \multirow[t]{2}{*}{$\begin{array}{l}\text { Minor } \\
\text { allele }\end{array}$} & \multirow[t]{2}{*}{$\begin{array}{l}\text { Minor allele frequencies } \\
\text { in YRI }\end{array}$} & \multicolumn{2}{|c|}{$\begin{array}{l}\text { Minor allele } \\
\text { frequencies in } \\
\mathrm{SCD}\end{array}$} & \multirow[t]{2}{*}{$\begin{array}{l}\text { Association } \\
p \text { values }\end{array}$} \\
\hline & & & & & AVN & Non-AVN & \\
\hline $\operatorname{rs} 267196^{\mathrm{a}}$ & BMP6-1 & Chr6: 7794334 & $\mathrm{~A}$ & 0.24 & 0.29 & 0.30 & 0.895 \\
\hline rs9392924 & BMP6-2 & Chr6: 7740099 & G & 0.48 & 0.35 & 0.38 & 0.600 \\
\hline rs3812163 & BMP6-3 & Chr6: 7670759 & A & 0.30 & 0.18 & 0.31 & 0.021 \\
\hline rs9526990 & $K L-1$ & Chr13: 32510826 & G & 0.25 & 0.29 & 0.29 & 0.966 \\
\hline $\mathrm{rs} 211239^{\mathrm{a}}$ & $K L-2$ & Chr13: 32494189 & $\mathrm{C}$ & 0.19 & 0.22 & 0.21 & 0.763 \\
\hline rs 8028846 & $A N X A 2-1$ & Chr15: 58472000 & G & 0.22 & 0.36 & 0.33 & 0.295 \\
\hline rs $7170421^{\mathrm{a}}$ & $A N X A 2-2$ & Chr15: 58421440 & $\mathrm{C}$ & 0.28 & - & - & - \\
\hline
\end{tabular}

Allele frequencies between the AVN group and the non-AVN group were compared using Pearson's chi-square statistical analysis with one degree of freedom; '-' denotes that the SNP assay did not work

${ }^{a}$ The SNP was also genotyped by Baldwin et al. [1] 
cartilage, supporting a role for BMP6 in the pathogenesis of this complication.

Association studies which examined polymorphisms in MTHFR [5], platelet glycoprotein IIIa (ITGB3) [6], and plasminogen activator inhibitor-1 (PAI-1) [7] with AVN in SCD in small numbers were non-conclusive. Another study sought association of combined vaso-occlusive complications including stroke, acute chest syndrome, AVN, and priapism with polymorphisms in candidate genes [8]. In this small study ( 34 cases and 63 case controls), association was found with a SNP in human platelet antigen-5 (HPA-5b allele) gene. Most of the events were AVN, with only four individuals having more than one complication. Similarly, numerous association studies with candidate genes for the other complications of SCD-stroke [9], priapism [10], and pulmonary disease [11] have been published, but to our knowledge, none of the associations have been replicated.

We acknowledge that our study was limited by the small sample size. While absence of AVN in case controls was not verified by radiologic exam in all cases, and thus may have included some patients with early AVN who were still symptom-free, the AVN cohort included only those with radiological and/or MRI evidence of AVN.

This study did not replicate the association between variants in $K L$ and $A N X A 2$, and AVN, shown in earlier studies [1]. $K L, A N X A 2$, and $B M P-6$ were also shown to be associated with other vascular complications in SCD such as priapism [10] and stroke [12], suggesting a common underlying molecular basis for these vascular complications.

Future clinical investigations should aim at replicating these findings including higher resolution genotyping in the region of the $B M P 6$ gene to identify the causal variant involved in sickle AVN. Large and appropriately powered studies designed for genetic analysis are required for such investigations.

Acknowledgment This work was supported by the Medical research Council (MRC, UK) grant G0001249, ID 56477 to SLT.

\section{References}

1. Baldwin C, Nolan VG, Wyszynski DF, Ma QL, Sebastiani P, Embury SH, Bisbee A, Farrell J, Farrer L, Steinberg MH (2005)
Association of klotho, bone morphogenic protein 6, and annexin A2 polymorphisms with sickle cell osteonecrosis. Blood 106:372375 doi: $10.1182 /$ blood-2005-02-0548

2. Erlacher L, McCartney J, Piek E, ten Dijke P, Yanagishita M, Oppermann H, Luyten FP (1998) Cartilage-derived morphogenetic proteins and osteogenic protein-1 differentially regulate osteogenesis. J Bone Miner Res 13:383-392 doi:10.1359/ jbmr.1998.13.3.383

3. Gitelman SE, Kobrin MS, Ye JQ, Lopez AR, Lee A, Derynck R (1994) Recombinant Vgr-1/BMP-6-expressing tumors induce fibrosis and endochondral bone formation in vivo. J Cell Biol 126:1595-1609 doi:10.1083/jcb.126.6.1595

4. Bobacz K, Gruber R, Soleiman A, Erlacher L, Smolen JS, Graninger WB (2003) Expression of bone morphogenetic protein 6 in healthy and osteoarthritic human articular chondrocytes and stimulation of matrix synthesis in vitro. Arthritis Rheum 48:25012508 doi: $10.1002 /$ art. 11248

5. Adekile AD, Kutlar F, Haider MZ, Kutlar A (2001) Frequency of the $677 \mathrm{C} \rightarrow \mathrm{T}$ mutation of the methylenetetrahydrofolate reductase gene among Kuwaiti sickle cell disease patients. Am J Hematol 66:263-266 doi:10.1002/ajh.1055

6. Zimmerman SA, Ware RE (1998) Inherited DNA mutations contributing to thrombotic complications in patients with sickle cell disease. Am J Hematol 59:267-272 doi:10.1002/(SICI)10968652(199812)59:4<267::AID-AJH1>3.0.CO;2-W

7. De Castro L, Rinder HM, Howe JG, Smith BR (1998) Thrombophilic genotypes do not adversely affect the course of sickle cell disease (SCD). ASH Annual Meeting Abstracts, p 161a

8. Castro V, Alberto FL, Costa RN, Lepikson-Neto J, Gualandro SF, Figueiredo MS, Annichino-Bizzacchi JM, Saad ST, Costa FF (2004) Polymorphism of the human platelet antigen-5 system is a risk factor for occlusive vascular complications in patients with sickle cell anemia. Vox Sang 87:118-123 doi:10.1111/j.14230410.2004.00536.x

9. Hoppe C, Klitz W, Cheng S, Apple R, Steiner L, Robles L, Girard T, Vichinsky E, Styles L (2004) Gene interactions and stroke risk in children with sickle cell anemia. Blood 103:2391-2396 doi:10.1182/blood-2003-09-3015

10. Nolan VG, Baldwin C, Ma Q, Wyszynski DF, Amirault Y, Farrell JJ, Bisbee A, Embury SH, Farrer LA, Steinberg MH (2005) Association of single nucleotide polymorphisms in klotho with priapism in sickle cell anaemia. Br J Haematol 128:266-272 doi:10.1111/j.1365-2141.2004.05295.x

11. Sharan K, Surrey S, Ballas S, Borowski M, Devoto M, Wang KF, Sandler E, Keller M (2004) Association of T-786C eNOS gene polymorphism with increased susceptibility to acute chest syndrome in females with sickle cell disease. Br J Haematol 124:240 243 doi:10.1046/j.1365-2141.2003.04762.x

12. Sebastiani P, Ramoni MF, Nolan V, Baldwin CT, Steinberg MH (2005) Genetic dissection and prognostic modeling of overt stroke in sickle cell anemia. Nat Genet 37:435-440 doi:10.1038/ng1533 